\title{
Granulocytic sarcoma of the choroid plexus complicating acute leukemia
}

Figure MRI
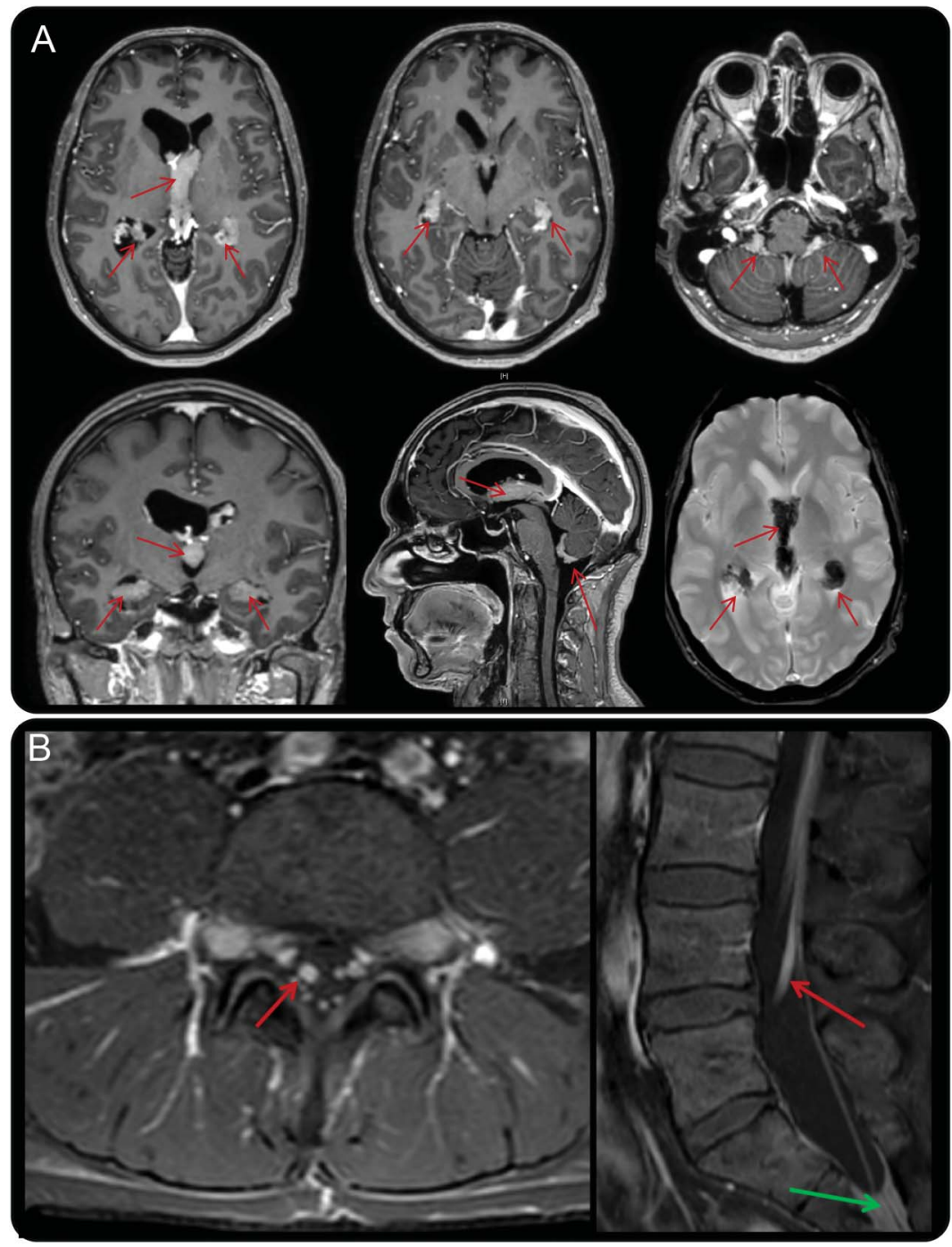

(A) Brain MRI (gadolinium-enhanced T1 sequences and T2*) shows granulocytic sarcoma of the choroid plexus. Choroid plexuses are diffusely enlarged (arrows), without hydrocephalus. Note that there is no associated meningeal lesion. (B) Lumbar MRI shows signs of neoplastic meningitis: epidural infiltration in the cauda equina (green arrow) and enlargement with enhancement of L5 (red arrows).

A 38-year-old patient with type 5 acute myeloid leukemia relapsed after 4 years of treatment including chemotherapy and bone marrow transplant. He underwent imaging for vertigo, with an otherwise normal neurologic examination. Brain MRI showed diffuse choroid plexus enlargement, without hydrocephalus, a rare typical image of granulocytic sarcoma (figure, A). ${ }^{1}$ The patient also had spine MRI, to explore right L5 radiculopathy, which showed signs of meningitis with radicular and diffuse epidural enhancement (figure, B). 
Granulocytic sarcoma, or chloroma, is a tumor composed of immature granulocytes, associated with systemic leukemia, usually acute myelogenous leukemia. Common locations are soft tissues, bone, peritoneum, and lymph nodes.

Caroline Apra, $M D, M S c$, Pierre Bourdillon, $M D, M S c$

From Sorbonne Universités (C.A., P.B.), Université Pierre et Marie Curie; Brain and Spine Institute (C.A., P.B.), INSERM U1127, CNRS 7225, Paris; Department of Neurosurgery (C.A., P.B.), Hospices Civils de Lyon, Hospital for Neurology and Neurosurgery Pierre Wertheimer; and Université de Lyon (P.B.), Université Claude Bernard, France.

Author contributions: Caroline Apra: drafting/revising the manuscript, study concept or design, analysis or interpretation of data, accepts responsibility for conduct of research and final approval, acquisition of data. Pierre Bourdillon: drafting/revising the manuscript, accepts responsibility for conduct of research and final approval, study supervision.

Study funding: No targeted funding reported.

Disclosure: The authors report no disclosures relevant to the manuscript. Go to Neurology.org for full disclosures.

Correspondence to Dr. Apra: caroline.apra@neurochirurgie.fr

1. Guermazi A, De Kerviler E, Zagdanski AM, Frija J. Diagnostic imaging of choroid plexus disease. Clin Radiol 2000;55:503-516.

\section{Save These Dates for AAN CME Opportunities!}

Mark these dates on your calendar for exciting continuing education conferences by the American Academy of Neurology. Learn more at AAN.com/conferences.

Breakthroughs in Neurology Conference

- January 12-15, 2018, Orlando, FL, at the Caribe Royale Orlando

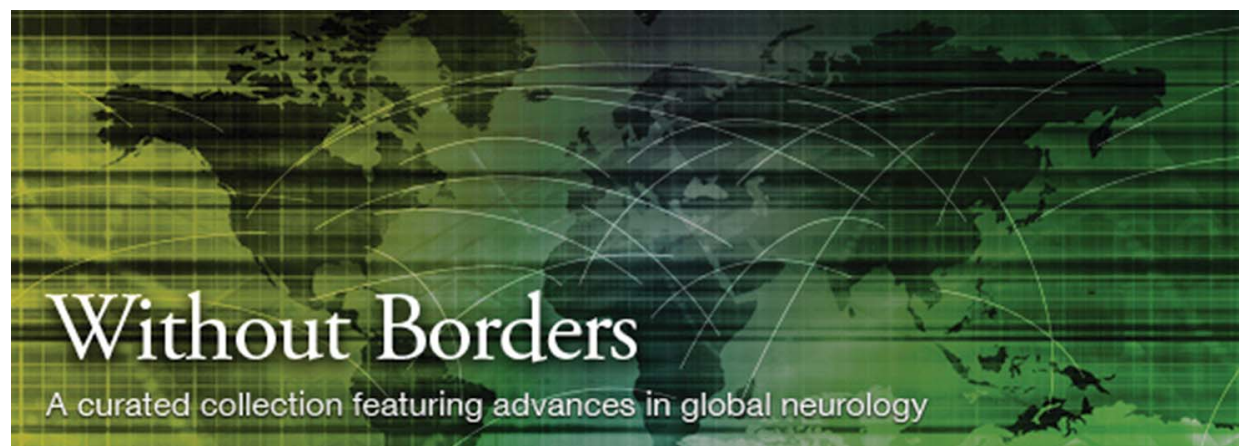

\section{Without Borders - A curated collection featuring advances in global neurology}

This Neurology ${ }^{\circledR}$ special interest Web site is the go-to source for tracking science and politics of neurology beyond the United States, featuring up-to-the-minute blogs, scholarly perspectives, and academic review of developments and research from Neurology journals and other sources. Curated by Gretchen L. Birbeck, MD, MPH.

Expand your world view at Neurology.org/woborders. 


\section{Neurology}

\section{Granulocytic sarcoma of the choroid plexus complicating acute leukemia Caroline Apra and Pierre Bourdillon \\ Neurology 2017;89;2019-2020 \\ DOI 10.1212/WNL.0000000000004632}

\section{This information is current as of November 6, 2017}

Updated Information \& Services

References

Subspecialty Collections

Permissions \& Licensing

Reprints including high resolution figures, can be found at: http://n.neurology.org/content/89/19/2019.full

This article cites 1 articles, 0 of which you can access for free at: http://n.neurology.org/content/89/19/2019.full\#ref-list-1

This article, along with others on similar topics, appears in the following collection(s):

Hematologic

http://n.neurology.org/cgi/collection/hematologic MRI

http://n.neurology.org/cgi/collection/mri

Information about reproducing this article in parts (figures,tables) or in its entirety can be found online at:

http://www.neurology.org/about/about_the_journal\#permissions

Information about ordering reprints can be found online:

http://n.neurology.org/subscribers/advertise

Neurology ${ }^{\circledR}$ is the official journal of the American Academy of Neurology. Published continuously since 1951, it is now a weekly with 48 issues per year. Copyright (O 2017 American Academy of Neurology. All rights reserved. Print ISSN: 0028-3878. Online ISSN: 1526-632X.

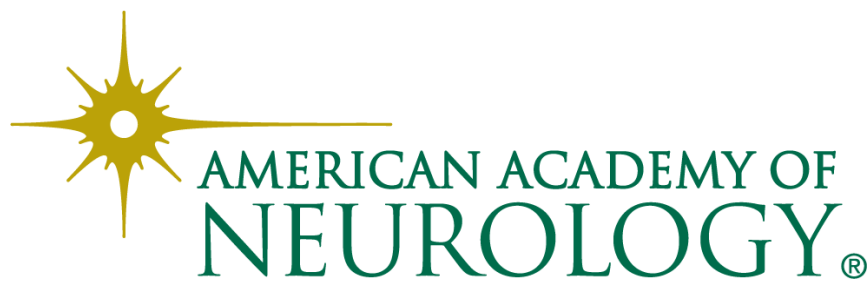

